\title{
Zenés előhang, avagy jelentések jelentősége
}

\author{
A. GERGELY ANDRÁS ${ }^{1}$
}

Az előhang mindig valamiféle csali-csel, hangoló magyarázat, meg kedvcsináló is. Főképp, ha kottaképek nélküli „prelúdium”, már-már kétségessé is válik, hogy muzikológiai kisesszé vagy Adorno iskolájából fakadó zenefilozófiai szaktanulmány hangzik ki belőle. Az alábbi írás kevesebb is, másabb is. Bevezető, voltaképp „házi próba” előtti hangolás, még színpadra, tudományos vagy alkalmazott művészeti porondra állást előlegző hangpróba. A „műsoron” egy korábban nem, vagy csak itt-ott is alig létező műfaj, a zenei antropológia első szólampróbája látható. Mint körvonalazó írás nem merőben szaktudományi, de valamely szaktudomány felől nézve is köztes, átmeneti, keletkező és kísérleti. A kompozíció lényege és célja az, kiderüljön, vagy legalább megfontolások során tesztelhető legyen, hogyan van jelen a zene a politikában, máshonnan nézve meg a politika a zenében. A két aspektus együtt a politikai antropológia és a zenei antropológia határmezsgyéjén billeg, maga sem eldöntve, melyik az érvényes nézőpont, s melyik határozza meg a későbbiek valószerűségét. Az átmeneti müfajt itt most zeneantropológiának nevezem. Nem biztos, hogy minálunk is van ilyen, de a világban sok helyütt van, s idővel itt is helyét találja majd. Ez most csupán egy kísérlet, avagy ahogyan Jeney Zoltán zeneszerző egyszer megfogalmazta: „spekuláció nélkül nincs intuíció”, ${ }^{2}$ tehát ha nem is gondolkodunk róla, akkor bizonyosan nem is lesz még egy ideig.

Ugyanakkor már jelen is van, csupán „neve” nincs. Hiszen ki ne ismerné vagy akár kedvelné is a renaissance udvari zenéit, Händel Tüzijáték-szvitjét vagy Vízizenéjét, Bach oratóriumait, Mozart Rekviemjét, Haydn kamaramuzsikáját és más jeles opuszokat, ha a klasszikus hangélményekről esik szó...? S ki (ne) gyanakodna, ha ezzel párhuzamosan az is fölmerül: egy induló, himnusz, fohászkodó ének, egyházi oratórium, Beethoven Fideliója, indián flótamuzsika, balinéz udvari szertartási csengettyűszó, mali blues vagy marokkói gnawa celebráció egyúttal politikai beszédmód is...? Mert hát mikor és miért válik egy nemzeti jelkép „ellenbeszéddé”, egy világbéke-dal divatossá, egy Hair-filmbetét korszakossá, egy táncházi cigánytánc kultikussá? Kivált-e társadalmi szolidaritást egy munkásmozgalmi himnusz, ha egy üzemi „kultúr-körben” hallgatják, s ha netán utcára viszik, vagy állampárti kultusz-

\footnotetext{
${ }^{1}$ ELTE TáTK Kulturális Antropológia Tanszék, e-mail: andrasgergelya@gmail.com

2 Spekuláció nélkül nincs intuíció - „Jób könyvé”-től a fraktálokig (Jeney Zoltánnal beszélget a „Halotti szertartás"-ról Farkas Zoltán) www.holmi.org/pdf/holmi2006-07.
} 


\section{VÉLEMÉNY}

szá silányítják? Akkor már közvetlenül is politikai az addig fóképp csak zenei? De megélhetést kínál-e dél-amerikai utcazenészeknek, ha európai fővárosok fóterein hangászkodnak, s dalaikban a politikai ellenállás, a forradalom, a szabadság-érzület, a békevágy fogalmazódik meg? S lehet-e ezekből is következően „politikai beszédmódnak" tartani azt, ami nem politikainak indult, hanem hagyományhűségnek, kulturális örökségnek, mindennapi élet rítusaiba illeszkedő szakrális műfajnak, szórakoztató játéknak vagy közérzületi fohásznak akár?

Pár éve, hogy e kérdéseket körvonalaztam, szakmai körökben „teszteltem”, s arra jutottam, hogy nem foglalkoznak ilyesmivel a társadalomkutatók, még kevésbé a politológusok, s csak hébe-korba a néprajzkutatók, annál is ritkábban a zeneelméléncek. Pedig megannyi dimenziója e kérdéseknek alaposabb áttekintésre, árnyalt asszociációkra is késztethet bennünket. Az alábbi szöveg nem új, csupán egy tudományos vállalkozás kezdeteit, talán első összeállítás merészségét tükröző kísérlet: bevezetés egy zeneantropológiai tanulmánykötethez, melynek jelentésterében a politikai gondolkodás, politikai magatartás, a jelképes beszéd egy sajátos értelmezési tartománya kapott fó hangsúlyt. Jelentések és jelentősségek szemléje tehát ez: a jelentések erdejében, vagy azon túl is a nyomatékos hatások közegébe, társas és közösségi élményvilágba kalauzoló válogatás. Jelentőssé azért válhattak a szóban forgó témakörök, mert jelentésük/jelentéseik világában a jelentéstársítások összhatása tette őket többletjelentésűvé, korszakossá, tartalmassá. Mert hát állítaná-e akárki, hogy nincs sajátlagos bűvköre és ellenkulturális tartalma a kalotaszegi cigányzenének (melyről Könczei Csongor kiváló monográfiát írt) vagy a náci rockzenének (Pulay Gergely elemzései korszakmeghatározóvá váltak), a „manele-mixeknek" vagy a Kallós-gyüjtéseknek, de akár Maszkura és a tücsökraj üzeneteinek, az egyházi könnyűzene kultuszköreinek és a karizmatikus közösségek lelkiségének (például Povedák Kinga elemzéseiben), az andoki „slágereknek” („El condor pasa”) vagy a Marseillaise-nek? S lehet-e mindezt „politikamentesen” átérezni, hallgatni, értelmezni?

Meggyőződésem, hogy nem. Azaz lehet, de nem érdemes, mert csupán szűkítő értelmezéshez jutunk, melyből épp a lényeg hiányzik... Az alábbi könyvbevezető, tanulmánykötet-előszó erről érintőlegesen szól csupán, de talán elkalauzol a zene és/ vagy politika mögöttes tartományai felé. ${ }^{3}$ Érdemes jelezni, hogy a témakör kutatásai nem értek véget e válogatás közreadásával, sőt egyre tágabb körben gazdagodik egy következő elemzésgyűjtemény, melyben már sokszorozódik zene és politikai cél, hallgatói és alkotói kisebbségek vonzáskörének átalakulása, az antipolitika és celebritás, szakrális műfajok és kultuszok, sámánzenéktől rituális dobolásig, vagy átírt nemzeti himnuszoktól a retro-Jimi Hendrix revivalig ívelő ikonikus jelentéskeresés, sőt akár a minap bemutattam újabb kötetig, mely Dalos Anna monográfiája a Ká-

\footnotetext{
${ }^{3}$ A teljes szöveg elérhető itt: http://mek.oszk.hu/10200/10296/index.phtml.
} 


\section{VÉLEMÉNY}

dár-korszak zenében, a zeneszerzők munkásságában tükröződő politikai alaptónusokat vizsgálva ezek „hangászati kultúrharcban” megjelenő felhangjairól...4

A jelentőség már adott, a jelentések fölfedezése azonban sosem múlt idejű, sőt leggyakrabban épp a jelen feladata...!

\section{Zene mint politika? A kötet írásai elé}

Egy (jó pár éve) megjelent kötet ${ }^{5}$ ürügyén kerítek sort itt olyan kérdések felvetésére, melyek a kortárs kultúrakutatás területén meglehetős közelségben vannak a nemzeti, etnikai, kisebbségi múvészeti területekkel és azok kutatásával is. Egy tudományos ismeretközlő mű, elsősorban bölcsész- és társadalomtudományi érdeklődésű olvasókra számító összeállítás szerkesztőjeként teszem ezt, szinte nyilvánvaló elfogultsággal. Mint szerkesztő, a magyarországi egyetemi oktatásban és tudományos kutatásban ritka, pontosabban eddig még nem létező tematikájú válogatásban két (látszólag egymástól távoli) terület összefüggéseire építettem föl azt a komplex megismerés- és megközelítésmódot, amelyet a nyugati tudományosságban a zenei antropológia (és részben az etnomuzikológia) képvisel. Ez a terület csupán egy-két hazai kutató munkásságának margóján sejlik föl, szélesebb körben nem is ismert, s még kevésbé használt megismeréstudományi tematikát ölel át. Rövid összegzésben azt a (majdnem kézenfekvő, de zenetudományi kutatásokból közvetlenül korántsem igazolható) feltevést lehet mindebből kiemelni, amely zene és politika összefüggéseire épül. Számos távoli társadalomtudományi tudásterület felől kevésbé értelmezhető, miként függ össze a zenei kultúra a politikai kultúrával, avagy a zenei aktivitás a politikai részvétellel - de e köztes tartományban ugyanakkor olyan átmeneti vagy szubkulturális szcénák, élményközösségek és értelmezési horizontok vannak, melyeken belül a társadalmi kultúrafogyasztás és kultúraformálás, interetnikus kommunikáció és művészeti-alkotói kifejezésgyakorlat minden másnál evidensebb.

A tanulmányválogatás szerzői, akiknek háromötöde egyetemi-főiskolai korosztályból való, empirikus tapasztalat és résztvevő megfigyelés során mutatják be azokat a kortárs városi csoportszerveződési mintákat, melyek többsége valamely zenei csoportérdeklődés, társas időtöltés, értékrend és létmód megtestesítője. Nem politikai rendezvények „házi zenekarairól” van itt szó természetesen, hanem olyan zenei események politikai jelentésrétegeiről, olyan dramaturgiai történésekről, amelyek szcenikai és téri értelemben az ifjúsági, korosztály- és etnospecifikus szubkultúrákba települnek, s magában a fogyasztói kultúra speciális rétegében válnak politikai

${ }^{4}$ Lásd bővebben: https://sites.google.com/view/peri-mikro-szkp/rendszerv\%C3\%A1lt\%C3\% B3-89/m\%C5\%B1v\%C3\%A9szethatalom-margin\%C3\%A1lis-zene-hang\%C3\%A1szati-kult\%C3\%BArharc.

${ }^{5}$ A. Gergely András (szerk.): Zene és/vagy politika. Zeneantropológiai megközelítések. MTA PTI Etnoregionális és Antropológiai Kutatóközpont, Budapest, 2011., Munkafüzetek 112. 


\section{VÉLEMÉNY}

természetűvé vagy politikai jelentőségűvé. E jelentéstulajdonítás nem föltétlenül a szerzők játszmája, hisz immár nem is egyetlen csoportkultúra épül a rajongók tömegére (Edda, VHK, Balaton, Makám, Afro Magic, HaGesher, Ghymes, Bes o drom, Kanizsa Csillagai, stb.), mely kulturális fogyasztásnak, tér- és identitáskeresésnek ugyanakkor éppen a politikai szimbolizációs szcénákban lesz megváltozott tartalma: hol beszúkült társadalmi csoport intimitásának formálója, hol tömegbefolyásolásra épülő attrakció, hol ellenkultúra vagy „ellenbeszéd”, harsány vagy demonstratív sugárzás, kulturális hovátartozást és térbeli tagoltságot tükröző narratíva arcát ölti. Mindezek mélyén a „nempolitikai politika”, a rejtett kulturális és identikus elemek, a szimbolikus politikai befolyásolás kap kitüntetett szerepet, s maguk a fogyasztói körök, befogadók és kulturális piacszervezők is e funkciók mentén használják ezeket a kulturális mintákat vagy élik át az összetartozás élményét.

Jellegadó az említett térbeliség is, amely nemcsak a rurális kulturális térben, de sokkal inkább a nagyvárosi szcénában megjelenítve mutatja meg eltérő arculatait és struktúráját: a fővárosi party-élet egyes helyszínei, a kőszínházi-színpadi kínálat vagy az utcazenélés épp oly széles skálán osztja meg a befogadói rétegeket, mint a hozott, kapott, átvett, követett zenei minták, a kulturális örökség adott állapota és befogadói tábora. A zene életének szociológiája (ahogyan Losonczi Ágnes egykor népszerű kötete mutatta) a legváltozatosabb kulturális transzferek helyszíne: korosztályi/élethelyzeti, fővárosi/vidéki, tömegkulturális/magaskulturális, marginális/ kultuszos, fogyasztói/ellenkulturális, lokális/globális, etnospecifikus/interetnikus, tradicionálisan magyar/világzenei narratívák épülnek ki a csoportszintű kulturális térben. Részint ezek megmutatása, részint a zenei fogyasztás és „termelés” szempontjából tagolt kulturális rajzolatok fontosabb térpontjainak kijelölése adja meg azt a politikai jelentéshátteret, amelyben mind a sugárzó hatásoknak, közlésnek és befogadásnak, mind a piaci kínálatnak, fogyasztói érzékenységnek, vagy a társadalom önnön színpadra viteli játszmáinak mind-mind megvannak a szereposztási-funkcionális és a jellegzetes befogadói-fogyasztói jelentéstartalmai.

A kötet írásainak java része eltér a klasszikus szociológiai vagy szociálpszichológiai, s jobbára még árnyaltabban különbözik a korszakos hatásúan „népművelö” jellegú közösségfelfogások tudományos interpretációitól. Az ifjúsági szubkultúrákat a nyolcvanas évektől intenzívebben elemző kutatások - bár jó néhány alaptanulsággal szolgáltak - a mai fiatalabb korosztályok rétegjellemzőit, hovátartozás-keresési stratégiáit, életvezetési modelljeit már nem tudják igazán követni, mert ezek hibridizációs hatásoknak kitettek. Míg például az ifjúsági szórakozóhelyek szocializmus kori funkcionálásában csak lassú átalakulás-vizsgálat mutathatta ki a teljes alkoholtilalom felől a funkcionális alkoholizálás felé való eltolódást, ezt a tranzíciós hatást a drogfogyasztás terén példátlan sebességű változás múlta felül: a nyolcvanas-kilencvenes évek ifjúsági szubkultúra-kutatási tapasztalatai szinte ősmúlt idők tudását tükrözik a mai party-szcénában és technokultúrában megvalósuló játszmákhoz 


\section{VÉLEMÉNY}

képest. De nemcsak a pszichedelikus kábulat iránti vágy, hanem maguknak a szeánszoknak térbeli áthelyeződése, teresedése is újfajta megismerésmódokat sürget, s ezek egyikeként ez idő szerint leginkább a kulturális antropológia képes arra, hogy élményközvetlen tudást hozzon a szociológiai mércével már nem átfogható tömegú, finom belső változásokról. A party-helyszínek áthelyeződése a félprivát vagy „alternatív" szférába, továbbá a szakrális-rituális terek megsokasodása már nem csupán az átfogó képletalkotást teszi lehetetlenné vagy érvénytelenné, de maguknak az érintett ifjúsági szubkultúráknak sem szolgál kielégítő leírással. Nem is beszélve azokról a miliőkről, amelyekben nem a korosztályiság kap főszerepet, hanem a kollektivitás élménye, az esemény-fókuszált jelenlét, a mozgásdinamizmusok új pályái, a kapcsolathálózatok tagolódása lokálistól globálisig terjedően, vagy az identikusan vállalt, korosztály-független létformák képlékeny-tünékeny állapotai.

A kötet írásaiból egykönnyen kiolvashatóan itt még az interdiszciplinárisnál is komplexebb (pluridiszciplináris, esszencialista, metadiszciplináris?) megközelítésmódról van szó. A folyamatok átlátása nemcsak az időhorizonton való tájékozott eligazodást, de egyúttal az émikus, belülről és lényegi sodrások felőli megértést igényli. A szervezőelvek átlátása is már-már politológiai aspektusokat igényel, a csoportközi mozgások és összefüggések tömeglélektani átlátást tesznek szükségessé, a korosztályi részkultúrák vagy tagoltságok pedagógiai-pszichológiai belátásokat sürgetnek, az érintettek és „tiszták”, „fan”-ok és „partizók” köreinek szegmentálódása szociodemográfiai szempontokat igényel, az etnospecifikus dimenziókról pedig csakis a mentalitás- vagy minoritáskutatások árulhatnak el részleteket. Mindezeknek összefüggése a korosztályi divatjelenségekkel, a nyugati populáris és elitkultúrából átszivárgó jelenségek fogyasztás-szociológiai tüneményei, továbbá a politikai pszichológia által traktált én-politikák, biopolitikák, test-politikák hatásmechanizmusai immáron olyan tudás-transzfert igényelnek, amely nem állhat egyetlen tudományterület fókuszában, hanem csakis interdiszciplináris vállalkozás lehetőségévé lehet. E köztességet és interferenciát tekinti eszközének ez a kötet, amely az intim utcazenéléstől a nagy tömegeket vonzó techno-partikon át és a mikrokulturális-kultikus miliőkben kialakult etno-műfajoktól a földrészeket megrengető vagy nagytérségi világzenei divathullámokig megannyi zenei teret fog át, hogy annak-azoknak nem direkten, hanem szimbolikusan politikai mivoltáról is árulkodjon.

A kötet írásai közt egyúttal a városi keretet (vagy kereteket, díszleteket, a társadalmi drámák színpadának látványelemeit, polisz-narratíváit) megnevező tanulmányok is helyet kaptak (nem véletlen a címadás sem), ami segít mindezt árnyaltabban belátni, miközben nem téríti el a figyelmet az antropológusok megfigyelésre, „betelepülésre", élményközeli együttélésre vállalkozó szemléletmódjáról. E metodikai és didaktikai háttér egyben a könyv esettanulmányait konvencionálisabb olvasatok számára is elérhetővé tévő körvonalakat ad, nem utolsósorban politikaiakat, avagy (még a politológia tudásterületén is újnak számító) szimbolikus-politikaiakat. Enynyiben a nem csupán tánc- vagy színházantropológiai megközelítésekre érzékeny- 


\section{VÉLEMÉNY}

nyé vált, de olykor azokat is magába foglaló tudásterület, a zenei antropológia hazai alapjait próbálja egy választott térben lefektetni. Mindezen diszciplináris belátások azt a komplexitást kontúrozzák, amely nélkül ma már az egyes tudásterületek a társadalmi tapasztalatnak csak egészen efemer jelenségeit tudhatják belátni. A kötet oktatásbeli használhatóságát segíti az is, hogy diákok, doktoranduszok és egyetemi oktatók köre szavatolja a komplexebb felhasználást és interdiszciplináris tudásátadási tapasztalatot.

Az alkalmi olvasót alighanem már a tartalomjegyzék vizitálásakor meglepheti, hogy a zene és a politika egymástól roppant távoli területek, ha akár a hétköznapi tudás, akár a politikatudomány etablirozott területeit nézzük. De csak látszólag azok.

A kortárs demonstrációs, tüntetési és online politizálási hajcihőben talán nem sokaknak tűnhetett fel a népi/társadalmi/szubkulturális követelések egyik leghangosabbika: „Több technót a Parlamentbe!”. ${ }^{\text {A }}$ 2010. október 3-án zajló demonstráció az önkormányzati választások napján zajlott, százakat vonzott a Kossuth térre, ahol a résztvevők harsányan követelték az „Állami Techno Rádió” alapítását, a „nemzeti kultúra felvirágoztatását”, „az alkotmány újraformálásának előestéjén nemzeti együttmüködést", minden településen biztosítandó szerkót, és a Parlament közismerten legjobb akusztikájú termének techno-party célú hasznosítását is. A Klub Rádió tudósítójának becslése szerint szavazni aznap mintegy tíz százalékuk ment el, de kezükben sörösdobozzal, szívükben szeretettel kezdeményezték az utca szintjén a techno-zene állami-nemzeti szintre emelésének célját és feladatát...

Akkor hát van-e, $\mathrm{s}$ ha van, miért nincs direkt összefüggés a politikaformálás és a zenei szubkultúrák, nemzeti aspirációk, imázsok és akusztikák között? Van-e önálló, vagy szűkebb jelentésterén túlmutató interpretációs szférája a gipsy-klezmer vagy roma rap zenei törekvéseknek, az andoki utcazenészek térfoglalásának a nagyvárosi főtereken, afrikai dobok vagy indonéz gamelán kommunikáció tereiben, balkáni revitalizációban és szibériai punkban, spanyol vagy görög, kelta vagy brazil akusztikus népzenei/világzenei újraéledésben? Nem szólva itt a Pussy Riot moszkvai metróban, Vörös téren, vagy a Megváltó Krisztus-székesegyházban kiprovokált villámcsődületeiről, az elgondolkodtató különbség mégis messzire hangzik, amikor az amerikai csavargó-blues a földrész country-zenéjévé válik, ${ }^{7}$ a pakisztáni népzenéből világzenévé lett már nem is beszélve, ${ }^{8} \mathrm{~s}$ odáig már nem is merészkedve, amikor a Refugees for Refugees szíriai, tibeti, pakisztáni, iraki és afganisztáni művészekből álló együttes AMINA lemeze a világelsők közé kerül, ${ }^{9}$ a Tartit tuareg női csoport három földrészen arat nemzetközi sikert a nők elnyomása elleni tiltakozás mellett, ${ }^{10}$ a mali

\footnotetext{
${ }^{6}$ A harmadik (Kossuth téri) TTP-buli megnyerte az év legjobb bulijának járó díjat az Antropos közönségszavazásán. Folytatni fogjuk, nem adjuk fel! Online: http://www.facebook.com/tobbtechnot

${ }^{7}$ https://www.youtube.com/watch?v=oica5jG7FpU

${ }^{8}$ https://www.youtube.com/watch?v=SDfELfpumEE

${ }^{9}$ https://www.youtube.com/watch?v=vcRIxvTq58M

${ }^{10}$ https://www.youtube.com/watch?v=9XuA8cdrR0s
} 


\section{VÉLEMÉNY}

blues polgárháborúból menekült zenészei orosz-japán-lengyel-olasz muzsikusokkal indítanak európai zenei karavánt a háború elleni tiltakozásként. ${ }^{11}$

Kötetünk zene és politika témakörével nem csupán a két attrakciós szféra egymást sokszorosan átszövő világait törekszik bevilágítani, de egyenesen a zenepoliti$k a$, a zene mint társadalmi életvilág befolyásolására tett kísérlet, valamint a zenében mint társadalmi cselekvésvilágban antipolitikus gesztusként funkciót nyert viselkedésmódok és kommunikációk (a zene mint politika) megközelítésére vállalkozik. A két szociokulturális térség távolságát, a társadalmi ritmust, a zene mint politikai beszédmód érvényesülésének strukturális konfliktusát éppen a politikatudomány hallja meg a legkevésbé... - külön is szakmapolitikai, akadémiai kérdés lehetne éppenséggel az: vajon miért? De mert akár a zenetudomány, zenetörténet, zeneesztétika és kortárs zenei világok felől nézve, akár a népzenekutatás, zenei divatok, tánc- és zeneantropológiai vizsgálódások tematikái felől mérlegelve sokszor éppen a konkrét szubkulturális kérdések és válaszok mutatnak rá cáfolataikkal a politikatudomány indokolatlan „süketségére”, az itt közölt írások javarészt e két terület összhangzatai$r a$ fókuszáltak. Többségük nem e kötetbe készült, egybeválogatásuk tehát némiképpen önkényes ezért. Azt azonban föltétlenül bemutatni hivatottak, amit egyébiránt a zene felől nézve már sokkal gyakrabban tematizáltak a zenehistória klasszikusai és még a klasszikus zenei szcénák kortársai is (teszem azt T. W. Adornótól Kodály Zoltánon át Juan Goytisolóig vagy Szabolcsi Bencéig és Losonczi Ágnesig), nevezetesen, hogy maga a zenei világ lényegében sosem volt politikamentes. Válaszformán csupán kellőképpen lapos lehet az állítás, hogy a politika világa sem volt soha zenementes. Erre részint a zenetörténeti kutatásokból megannyi példát lehetne idézni akár a magyar, akár az egyetemes etnokulturális vagy szubkultúra-szakirodalomból, akár a hazai táncház- és népzenei szakcikkekből Vitányi Ivántól Andrássy Máriáig s tovább, de ellenkezőleg már kevésbé: a politikatudomány ez irányú érdeklődése korántsem oly evidens, mint lehetne.

Nem annyira a kötet alaphangját, s még a legkevésbé sem a közölt tanulmányok hivatkozott szakirodalmi bázisát idézve, csupán a legfelszínesebb válaszra törekedve engedtessék meg néhány olyan asszociációra utalni, melyekből azután a legtájékozatlanabb olvasó is kinyerheti azt a sugallatot, mit várjon a kötettől. Ha csupán a legszemélyesebb szférából indulok, élménytapasztalatként idézhetem föl a hatvanas években Magyarországon (és persze - mondjuk Krakkót, Prágát leszámítva - talán az egész virulens szocialista tábort ide citálva) korszakosan jellemző gesztust, amely bármely fiatal lélekkel szemben, akinek fülét érintő hosszúságú haja volt, vagy kezébe fogott egy gitárt, a korszak antiimperialista ébersége azonnal „hippinek”, „,huligánnak" és antiszociálisnak minősített, akit iskolai osztályfőnöke vagy a sarki közrendőr is alapos gyanúval vegzálhatott azután, mint „látható fegyvert” viselőt. Érdemes a

\footnotetext{
${ }^{11}$ Azalai Project - Carovana in Musica, https://www.youtube.com/watch?v=rKsx-AH7TsM
} 


\section{VÉLEMÉNY}

kontraszt kedvéért persze azt is fölidézni, hogy a Beatles- vagy Rolling Stones-frizurák divatja, az apolitikus és antiimperialista hippi-kultusz a nyugati világban is korszakos ellenkultúra része volt - lehetett volna épp ezért a szocialista világban akár befogadott is. De nem volt, s aligha azért, mert a viselet a szocialista életmóddal vagy a kötelező katonai szolgálattal nem volt összeegyeztethető. Sokkal inkább azért, mert a viselet mint kódolt jel egyértelműen az individualitás hordozója is, amennyiben nem egyenruhába bújtatott, amennyiben egyénít, perszonális identitást idéz, a mássághoz tartozást nyilvánítja ki. Hasonlóképpen, mint a haj- vagy parókaviselet közép- és újkori divatja az arisztokratikus másság tükreként a megkülönböztetés megannyi jelével volt ékes, akár praktikus, akár egészségtelen voltával együtt is, mert messzire jelezte a hovátartozás és kiváltság türhetetlenségét, melynek olykor kevésbé látható tartozékai voltak az udvari és polgári kultúrákban is a hangszerek, a zenélés alkalmai, a zene mint szertartásosság vagy attrakció megnyilvánulásai éppúgy, miként a falusi kontratáncokban, lagzikban, lokális ünnepeken megszólaltatott plebejusabb hangtartományok. Érdemes talán emlékeztetni a képzőművészeti ábrázolásokon megmaradt „osztálykülönbségek” olyan jegyeire, melyeket a hangszerek jellemeztek: pásztorok furulyái és sípjai, postakürtök és viziorgonák, fóúri vacsorák kamarazenekarai és királyválasztások fanfárjai, polgári csemballók és klavikordok, viola da gambák és fuvolák, templomi kórusok és madrigálcsoportok, paraszti lagzik dudásai és katonai indulók trombitásai - mind-mind nemcsak zenei milióket, hanem a distinkció, a megkülönböztetettség jeleit is hordozták. De vajon érdemes-e folytatni a zenetörténeti kisenciklopédia helyett, miként „járt” evidens tartozékként az európai hangszerkultúráknál sokkalta ősibb eszköztár használata afrikai királyok megjelenéséhez, piramisok építéséhez, Jerikó falainak omlasztásához, kínai császárok felvonulásához vagy akár mexikói szakrális ünnepre híváshoz a legkülönb fúvós és ütőhangszerek végtelen tömege...? Senkit sem ér ismeretlen információként a monoton tevékenységek végzését könnyítő eszköztárba tartozó ütőhangszerek, szövegek, ritmikus beszédek, mantrák, munkadalok használata, s épp ily természetes szertartásosság veszi körül a születés, az avatások, a koszorúzások, gyászzenék, himnuszok, díszszemlék, felvonulások, állami ünnepek, katonai parádék sokaságát, a marsok-indulók funkcióját vagy a riadójeleket.

Ünnep és hétköznap, állami vagy egyházi, profán és szakrális, nemzeti vagy kisközösségi jelképtár hatja át tehát azt a szférát, melynek tematikus gazdagságát, ha a történettudomány olykor-olykor mégis, a politikai tudományok valamiért nem illették méltó figyelemmel. Pedig - ha most a messzi történeti példatártól közelebb mozdulnék - szinte nem kétséges, hogy a mai nigériai himnuszt a szovjet himnusztól, vagy a német nemzetépítés „mindenekfelettiségét” megéneklő Haydn-kompozíciót a székely himnusztól minden európai átlagember meg tudja különböztetni. S vajon ha a nemzetépítés állami himnuszokkal jár, ha az identitás kifejezése a roppant gyakori és meglehetősen karakteres zenei vagy hanghatásokban fogan meg, akkor miért is ne lennének ezek a maguk kontextusaiban politikaiak vagy politikai szimbo- 


\section{VÉLEMÉNY}

lizmusokban megnevezhetők...? Nem kívánnék itt Néró lantjáig, Berlioz napóleoni korszakra jellemző óriás-zenekaráig, Händel Tűzijátékjáig vagy a Hair antimilitarista propaganda-zenéjéig elkalandozni, mert ezt a zenetörténészek és az esztéták megannyi opuszban megtették már..., de még csak olyan hétköznapi jelrendszerekig sem keresnék utalásokat, mint egy indiai hajnali raga, egy európai déli harangszó, egy gamelán-zenekar vagy egy balinéz udvari táncjáték hangszimbolikája, a Marseillaise vagy a Gotterhalte, az El condor pasa vagy az Üdvhadsereg felvonulási zenéi, egy gyimesi cigányprímás nótája vagy a We are the World világzenei attrakciója - úgy vélem, mindezek külön-külön is (együttes tipizálásuk esélyével még annyira) bizton hordoznak annyi direkten politikai tartalmat, melynek megismerése nemcsak lehetőség, de a politikai kultúra (és megannyi esetben a kulturális politikák) belátásához érdemben hozzájárulhatna. Nem utolsósorban olyan léthelyzetek megítéléséhez-megértéséhez is, midőn mondjuk az MR2 Petőfi Rádió az aktuális intendáns nyomására a „Felhők jönnek Magyarországra...” dalszövegsor miatt kitiltja a lejátszási listákról a Pál Utcai Fiúk új, Balatonszepezd című számát ${ }^{12}$ - és nem 1963-ban, hanem 2011 februárjában. Dalpolitika a füleknek? Áthallások a burkolt félelmek mögött? Avagy mégis „Tilos az Á”? És a Sárga rózsa is?

A fenti példák valójában csak felhangolók kívánnak lenni. A kötetben közölt esettanulmányok ezeknél árnyaltabbak, konkrétabbak, élményközelibbek, de egyben ide is csatolják a társadalomkutatás módszertanának azt a viszonylag kevéssé ismert együttesét, melyet a kulturális antropológia (ágazatai, a történeti, a szimbolikus, a vallás- vagy közösségkutatások társterületeit is ideértve) kínál. A tanulmányválogatásban nem volt kizáró szempont, ha egyes írások inkább a szubkultúra-kutatások felől közelítenek, sem az, ha rítus- vagy élményközösségek alapján választanak társadalmi kutatási terepet. Viszont nem törekedtem teljessé tenni a képet olyan történeti szempontból fontos kutatásokra utalásokkal, vagy ezekről készült elemzésekkel, amelyek a direkt politikai zenebefolyásolás mechanizmusaira vonatkoznak, pl. a berlini zeneakadémiai oktatás fasizálódási időszakára vagy a szovjet mintájú munkadalok, csasztuskák, himnuszok, munkáskórusok, tömegrendezvényi zeneparádék ideológiai orientációjának körvonalazására, esetleg a zenebefogadás korosztályi konfliktusként, illetve technológiai forradalom részeként értelmezett kommunikációtudományi területére. ${ }^{13}$

\footnotetext{
${ }^{12}$ http://comment.blog.hu/2011/02/02/a_petofi_kicenzurazta_a_puf_ot

${ }^{13}$ Csupán utalásként lásd Fischer-Defoy, Christine (1988): Kunst Macht Politik. Die Nazifizierung der Kunst- und Musikhochschulen in Berlin. Elefanten Press, Berlin, 352 p.; Kovalcsik József (1986-87): A kultúra csarnokai I-II-III., Művelődéskutató Intézet, Budapest; Toelken, B. (1983): Pow-pow folklorism. In: Voigt Vilmos - Niedermüller Péter (eds.): Folklorismus Today, MTA Néprajzi Kutató Csoport, Budapest, 108-121; Brown, Karl (2008): Jazz and Hooliganism in Communist Hungary 1948-1956. Trondheim Studies on East European Cultures and Societies, No. 26. Trondheim, Norvay; Komoly zene. (tematikus szám) Replika 49-50., 2005. augusztus, 27-254; Losonczi Ágnes (1969): A zenei megértés fokozatai, a fejlődés társadalmi indítékai. In: A zene életének szociológiája. Zenemúkiadó, Budapest, 191-204; Tallián Tibor (1983): Cantata profana - az átmenet mítosza. Magvető, Gyorsuló idő, Budapest.
} 


\section{VÉLEMÉNY}

Az írások között egyaránt szerepel a tárgyalt szubkulturális miliőbe beleskelődő, hosszasabban ott tartózkodó, bevonódott és eltávolodott, azonosságot vállaló és distanciát tartó is, melyek magukat a szimbolizációs eljárásokat, a megismerési folyamatot, a feltárás mélységét és adott esetben a textust is meghatározzák. E textusok közös jellemzője, hogy nem okvetlenül törekedtek a tárgyalt zenei-szubkulturális világ direkten politikai kontextusainak leírására vagy megnevezésére, de olvasásuk közben nem lehet kétséges, mi keretezi, mi veszi körül a miliőt és szereplőit. Valamiképpen a társadalomtudományi kutatásoknak, elsősorban is a szimbolikus és a politikai antropológiának volt (időről időre, egyes alkotókra jellemző módon elemzésről elemzésre is) része annak a társadalmi nagyszínpadnak leírása, melyen az aktorok, a politikai érdekháttérből fakadó konfliktusok, a hatalom dramaturgiai szerepéből adódó szereposztások, a celebritások vagy szürke eminenciások közpolitikai funkciói is élő díszletek között reprezentálódnak. Ezt a szimbolikus politikai szférát, a sokmenetes játszmák és társadalmi drámák folyamatait kísérik azok a zenei attrakciók, performance-ok, rituálék és értékrendek, amelyek a kortárs kultúra megannyi csoportozatát magukba foglalják. ${ }^{14}$

A szerkesztő számára tehát nem kérdés: a politikai antropológia és a szimbolikus politikák tudástartományaitól a politikai etnográfián át a szubkulturális közösségkutatásokig jó néhány terület van, melyeken újszerü és interaktív tudásra, belátásra, elemzési tapasztalatra van szükség. Kiváltképpen arra, hogy az empirikus leírások elméleti horizontján fölsejlő összhangok, a közpolitikai diskurzusokban megjelenő disszonanciák, s nem utolsósorban a metaelméletek bázisán megtalálható élményközeli belátások harmonikus összképként kínáljanak a korábbiakhoz képest eltérő vagy hiányzó megközelítésmódokat. Mutatva nemcsak azt, mennyi asszociatív tere van „a zene” határait a társadalmi ritmusok, csoportléptékű szólamok, interkulturális kölcsönhatások, átvételek és cserék, formaváltások és stílusrögzülések felől taglaló kutatásának, hanem azt is modellezve, milyen metodológiai innováció vagy szemléleti reflektivitás szükséges ma már a legtriviálisabbnak tetsző hétköznapi események (buli, koncert, party-élet, utcasarki kultúrák, népzenei programok, ellenkulturális mozgalmak, „idegenforgalmi programok”, reggae fesztivál stb.) tereinket, nyilvánosságainkat és kommunikációinkat átrendező hatását érzékelni/érzékeltetni.

A kultúraközi randevúkat zenei oldalról szemügyre vevő intimitásoknak kultúraátvételi, fogyasztói piaci, egzotikum-forgalmazó és direkten világnézeti kikapcso-

\footnotetext{
${ }^{14}$ Lásd ehhez az előző jegyzetben utalt Toelken indián harci tánctípus-leírását, Losonczi ipari munkás-környezetben zajló művészetbefogadási rendszerelemzését, valamint Tallián vallások és társadalomelméletek archaikus mintázataiban jelen lévő közösségi-egyéni jelentésrendszerét, továbbá az utalt Replika-szám szinte valamennyi tanulmányát. Új tónust és tematikai horizontot nyit Povedák Kinga kötete, a Gitáros apostolok. A keresztény könnyűzene vallástudományi vizsgálata. MTA-SZTE Vallási Kultúrakutató Csoport, Szeged, 2019.
} 


\section{VÉLEMÉNY}

lódásra orientált értékelése egyformán jogos lenne itt. ${ }^{15}$ Hipotetikusan bizonnyal lehetne valamely kvázi-tipológiát megalkotni konzervatív-konvencionális műfajokból és kulturális ágakból (vö. népdal, cigányzene, induló, himnusz, egyházi zene, kórusmúvek, színpadi műfajok - opera, operett, musical -, ceremoniális vagy szakrális attrakciók, tájegységi népzenék, konvenciális műformák és műnemek stb.); ellenoldalon hasonló elem lehetne a konfrontatív (beat, punk, hardrock, polbeat, mozgalmi dal, rap, Commandante Che Guevara, El condor pasa, Hair stb.) értékeket szimbolizáló törekvések és korszakok sora; továbbá kézenfekvő volna posztmodern-törzsi (klezmer, gipsy, afro, ska, sátánisztikus, kelta, techno, sámánisztikus, hip-hop, egyházi rock, ${ }^{16}$ gnawa, ${ }^{17}$ capoeira stb.) múfaji besorolásban feltárni a funkcionális és strukturális hatásmechanizmusokat - de ez idő szerint erős a gyanúm, hogy maguk a múfajok és képviselőik tartanák a legképtelenebb ötletnek besoroltatásuk kényszerű rendszerét. Mi több, még az ellenében sem tudnék hirtelen érveket hozni, miért is volna szüksége éppen a politikatudománynak vagy politikai antropológiának arra, hogy saját kényelme érdekében, (Clifford Geertz szavaival) „a sokféleség édes haszna" ellenében kreáljon mesterséges kategóriákat épp azokra a jelenvalóságokra, melyek ekképpeni interpretációja csupán egyik, s nem okvetlenül a leghitelesebb a lehetségesek közül, továbbá nem a bennszülöttek, a jelenlévők, a szereplők és a szimbolikák értelmezésében éppoly jogosultak körére támaszkodik, hanem „fentről” formál elvont kategóriákat.

15 További források még: Journal Ethnologie: http://www.journal-ethnologie.de/Deutsch/; Schwerpunktthema: Devereux und die Ethnopsychoanalyse Georges Devereux (1908 Lugos, Bánát - 1985, Paris): http://www.journal-ethnologie.de/Deutsch/Schwerpunktthemen/Schwerpunktthemen_2009/Devereux_und_die_Ethnopsychoanalyse/Angst_und_Methode_in_den_Verhaltenswissenschaften/index.phtml; Trouillet, Jean Das Musikalische Wohnzimmer Eine Veranstaltungsreihe des Museums der Weltkulturen in Frankfurt am Main: http://www.journal-ethnologie.de/Deutsch/Weltmusik/Das_Musikalische_Wohnzimmer/index.phtml; Sibeth, Achim Jazz-Musiker und javanisches Gamelan Die Pata Masters mit Norbert Stein treffen auf die javanische Gamelan-Gruppe Kua Etnika von Djaduk Ferianto. Besprechung einer neuen CD: http://www.journal-ethnologie.de/Deutsch/Weltmusik/Jazz-Musiker_und_javanisches_Gamelan/ index.phtml; Ham, Peter van - Stirn, Aglaja Klänge von den Nebeln jenseits der Zeit Aus dem Liederbuch der Naga: http://www.journal-ethnologie.de/Deutsch/Weltmusik/Klaenge_von_den_Nebeln_jenseits_der_ Zeit/index.phtml; Schlottner, Michael „....make them to be songsters” Flötenmusik der Westküsten-Indianer: http://www.journal-ethnologie.de/Deutsch/Weltmusik/make_them_to_be_songsters/index.phtml; Sauer, Christian David Klänge von Autos, Sklaverei und Widerstand Der afro-brasilianische Musikbogen Berimbau: http://www.journal-ethnologie.de/Deutsch/Weltmusik/Klaenge_von_Autos=2C_Sklaverei_und_ Widerstand/index.phtml; Trouillet, Jean Derwisch-Musik Lieder und Musik im Industal Pakistans: http:// www.journal-ethnologie.de/Deutsch/Weltmusik/Derwisch-Musik/index.phtml; Povedák Kinga 2014 Az egyházi könnyűzene fogadtatása és megítélése a szocialista Magyarországon. In Vallás, egyén, társadalom. Szegedi Vallási Néprajzi Könyvtár / Bibliotheca religionis popularis Szegediensis 39. A vallási kultúrakutatás könyvei 7. SZTE BTK Néprajzi és Kulturális Antropológiai Tanszék, Szeged, 111-122.

${ }^{16}$ http://keresztenyrock.lap.hu/

${ }^{17}$ https://www.youtube.com/watch?v=bnixGjMhBJE 


\section{VÉLEMÉNY}

Tartózkodva tehát a mondvacsinált tipologizálástól, engedtessék arra késztetnem az olvasót, találjon maga besorolási modellt, interpretációs keretet, elbeszélésmódot e másságok saját célú kezeléséhez, s hagyja nyugodtan a megnyilatkozó szubkultúrákat akképpen mássá lenni vagy másnak maradni, ahogy céljaik, értékrendjeik, változási dinamikáik, összhangjaik és felhangjaik mentén mindez megvalósulhat... Egy „zeneantropolisz” számára ez lenne talán a legevidensebb lakosi, résztvevői jog, identikus állandó vagy élményközösségi hatáseszköz, mely segíthetné a hazai zeneantropológia kialakulásának és kibontakozásának első próbálkozásait. 